\title{
The Information System Project Profiles among Universities in Indonesia
}

\author{
A'ang Subiyakto ${ }^{1}$, Abd. Rahman Ahlan ${ }^{2}$, Mira Kartiwi ${ }^{3}$, Nashrul Hakiem ${ }^{4}$, \\ M. Qomarul Huda ${ }^{5}$, Aries Susanto ${ }^{6}$ \\ ${ }^{1,4,5,6}$ Syarif Hidayatullah State Islamic University Jakarta, Indonesia \\ ${ }_{2,3}$ International Islamic University Malaysia, Malaysia
}

\section{Article Info}

Article history:

Received Apr 9, 2018

Revised May 20, 2018

Accepted Jul 11, 2018

\section{Keywords:}

Descriptive results

Indonesia

Information system

Project profiles

Survey

\begin{abstract}
Information system (IS) utilizations may have been one of the determinant factors for the survival requirement of the higher education sector in Indonesia. Despite the IS projects have been conducted since the 1980s in this country, but many studies indicated that success of the projects seems like in the low level. This survey study was purposed to know the status of the IS project success among universities by involving the internal stakeholders. The higher education database of the Ministry of Research, Technology, and Higher Education (MRTHE) and the Association of Computing and Informatics Institutions Indonesia (ASCII-I) in the year 2015 were used for selecting around 1.230 respondents based on a purposive random sampling. The blended questionnaires were then distributed with almost $298( \pm 24 \%)$ responses. This paper presents five project profiles, including the aim, IS strategic plan availability, internal team involvement, budget allocation, and the success level of the projects.
\end{abstract}

Copyright @ 2018 Institute of Advanced Engineering and Science. All rights reserved.

Corresponding Author:

A'ang Subiyakto,

Syarif Hidayatullah State Islamic University Jakarta, Indonesia.

Email: aang_subiyakto@uinjkt.ac.id

\section{INTRODUCTION}

The beliefs of most current business thinkers in the higher education world towards the IS utilization may have been changing in this knowledge economy era. Like the other business sectors, the utilization for supporting the business operations has been a decrepit strategy, including for higher education institutions (HEIs) in the developing countries like Indonesia. Referring to the McFarlan's [1] strategic grid, the previous IS strategic planning studies (e.g.,[2-3]) indicated that the IS use has been shifted from the turnover quadrant into the strategic one. Besides the fact that the use is inevitable for covering the strategic, managerial and operational functions of the educational institutions [4-5], the functions seem like impossible to be done without using IS. For example, the IS implementation has become a necessity for the institutional accreditation and ranking in the national and international levels. It may be one of the reasons why the IS implementations have been one of the main focuses of every university in the country for the last decade, in respect of the globalization and change in higher education world [6].

Furthermore, despite it is like an excessive phobia towards the risks of the IS development projects among the stakeholders referring to the failure tendencies of the projects [7-11], the project success attainment is indispensable to get the benefits of the technological use [12-14]. The next point is how to ensure the success of the projects. Of course, it may not be a simple effort; but many literatures, e.g., [15-17] described that the first stage of the problem solving procedure is how to identify the problem itself. Thus, this study was performed to respond to the above-mentioned phenomenon, especially to know the project success status. On the other side, the similar studies which surrounded the matter are still rare, especially in the higher education world in Indonesia. 
During the preliminary term of the response, the purpose of the study was to identify the performance status of the IS projects among universities in Indonesia. The objective was to know the status based on the internal project stakeholders. Here, the IS project term was defined interchangeably with the information technology (IT) or information communication technology (ICT) projects referring to the term of $\mathrm{Xu}$, Zhang, and Barkhi [18]. Meanwhile, IS was referred to the convergence of telecommunication and computer technologies for deploying the business processes and services of an organization [19-20]. In regard to the purpose and objective of the study, the following research questions were then used for guiding the study implementation.

RQ1. What are the implementation goals of the IS projects among HEIs in Indonesia?

RQ2. What percentage of the ISSP availability among HEIs in Indonesia?

RQ3. What percentage of the internal team involvement in the IS projects?

RQ4. What percentage of the internal budget allocation in the IS projects?

RQ5. What is the success level of the IS projects?

The paper is staged within four sections. In the first section, the part elucidates the research programs, including the background, problem, purpose, objective, and the research questions. The researchers then demonstrate the methodological points of the study, including the population, procedure, sampling, data collection, analysis, interpretation, and the instruments of the study in the second section. The third section shows the results and its discussions. Lastly, the paper is concluded by the fourth section.

\section{RESEARCH METHODS}

Sequentially, Figure 1 presents the nine stages of the study. The population was a number of the internal IS project stakeholders among approximately 4.290 HEIs. The data were obtained from the Higher Education Database of the Directorate General of Higher Education (DGHE) MRTHE and ASCII-I, in the year 2015. In regard to representing and to legitimizing the population [21-22], considering the research resources [23] and the key informant points [24-25]; the purposive random sampling was then used in the study.

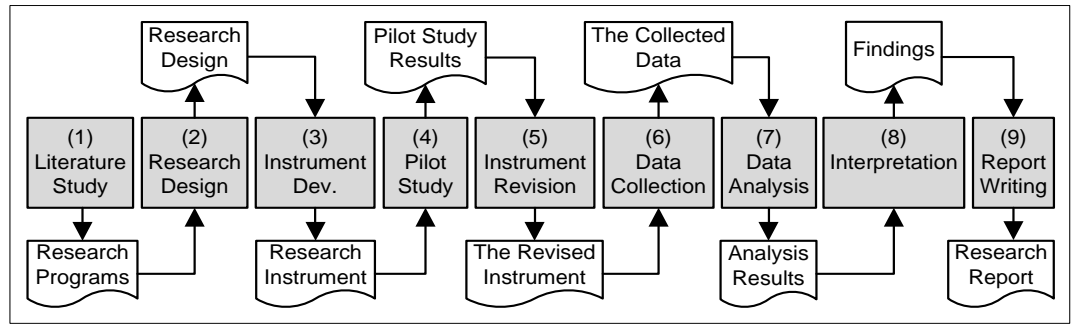

Figure 1. Procedure of the study

The blended survey was then purposely selected to obtain the experienced samples and randomly distributed into the selected samples. The combination aimed to ensure the spread of the data distribution, the response rate of the respondents, and the quality of the data [22, 26-27]. The online questionnaire was sent to around 1000 email address and almost 230 paper-based ones were distributed to the five selected cities. Approximately 296 valid answers ( $\pm 24 \%$ response rate) were then obtained from the on-line $( \pm 128$ responses) and the paper-based ( \pm 168 responses) surveys. The instrument set comprised of three components, i.e., the invitation letter, research overview and the questionnaire pages. The first two parts were specially developed to improve the response rate [28].

The questionnaire part comprised of two group items. The first three items were related to demographic information and the second five ones were expressed the IS project performance opinions of the respondents. In the data analysis stage, the researcher processed around 312 collected data into a spreadsheet form using the MS. Excel 2007, filtered the valid data ( \pm 296 data) by deleting 16 invalid ones because of the incomplete answers and then analyzed the data with the IBM-Statistical Package for the Social Sciences (SPSS) software version 20. However, it was developed by the three question items; the information presented six demographic points by filtering the data use the Higher Education Database of the DGHEMRTHE. The results were then interpreted by considering the findings of the previous pilot study and literature, in the estimation term rather than the examination purpose [29]. 


\section{RESULTS AND ANALYSIS}

\subsection{Demographic Information}

There are six characteristic points of the respondents, including the affiliation type, institution accreditation, territory origin, education level, experience duration, and the job position of the sampled people. The three first information points were produced by retrieving the Higher Education Database of the DGHE-MRTHE in the year 2015, following to the second three points. The aim was to emphasize the estimation function of the findings [29].

First, affiliation types of the respondents. The study results indicate that the numbers of both respondent affiliation types are demonstrated relatively within the equal rate Figure 2. In detail, the overall respondents were affiliated with the $129( \pm 3 \%)$ universities of the total 4.292 educational institutions in Indonesia. This comparison indication is inconsistent with the similar indication of the Higher Education Database of the country in the year 2015 .

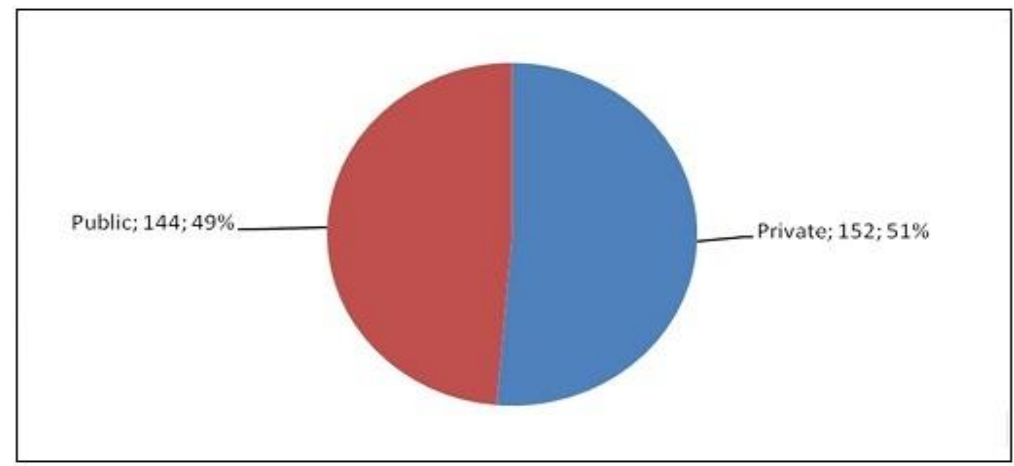

Figure 2. Affiliation types of the respondents

Second, affiliation accreditation levels of the respondents. Majority respondents $(n=208 ; \pm 70 \%)$ were from the accredited universities and the rests were the non-accredited ones Figure 3 . The highest number $(n=121 ; \pm 41 \%)$ was from $B$ grade and the lowest one $(n=14, \pm 8 \%)$ was from $C$ grade $(n=14 ; \pm 5 \%)$. As a comparison, the Database of the National Accreditation Body for Higher Education (NABHE) of the MRTHE (http://ban-pt.kemdiknas.go.id/) in 2015 presents that only 852 ( $\pm 20 \%)$ of the total HEIs $(n=4.292)$ were the accredited ones. It can be clearly seen that almost $70 \%$ of the respondents affiliate to around $24 \%$ of the accredited HEIs.

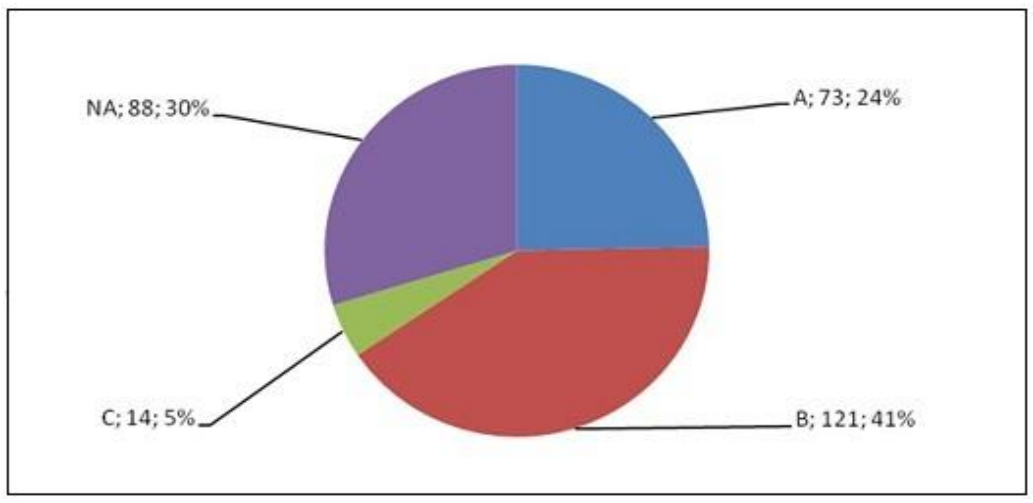

Figure 3. Affiliation accreditation levels of the respondents

Third, territory origins of the respondents. Referring to the seven main territories in the country, majority respondents were from the institutions in the Java area $(n=212 ; \pm 71 \%)$ and the minority people $(\mathrm{n}=2 ; \pm 1 \%)$ were from the Papua area Figure 4. This tendency is appropriate to the Higher Education Database in the country. 


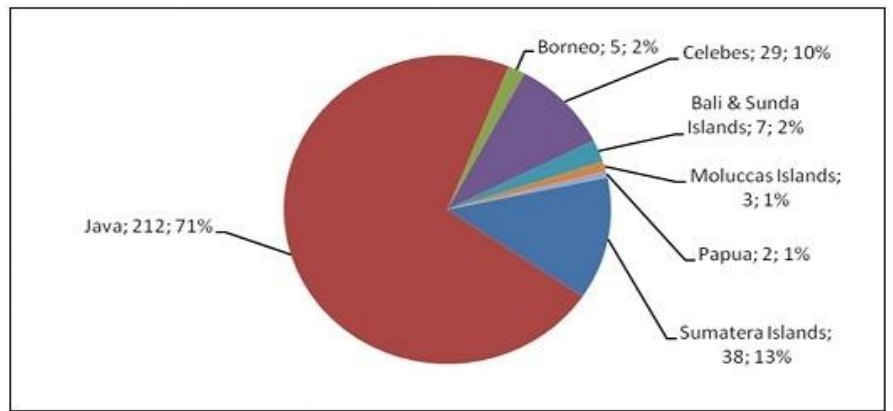

Figure 4. Territory origins of the respondents

Fourth, education levels of the respondents. The biggest sample was the master degree $(\mathrm{n}=155 ; \pm$ $53 \%)$ and the smallest one was the high school degree $(n=15 ; 5 \%)$ Figure 5. The results also present that majority samples $(n=281 ; \pm 95 \%)$ were the university degrees, including the diploma, bachelor, master, and the doctor degree within $63( \pm 21 \%), 17( \pm 6 \%), 155( \pm 53 \%)$, and $46( \pm 16 \%)$ numbers respectively.

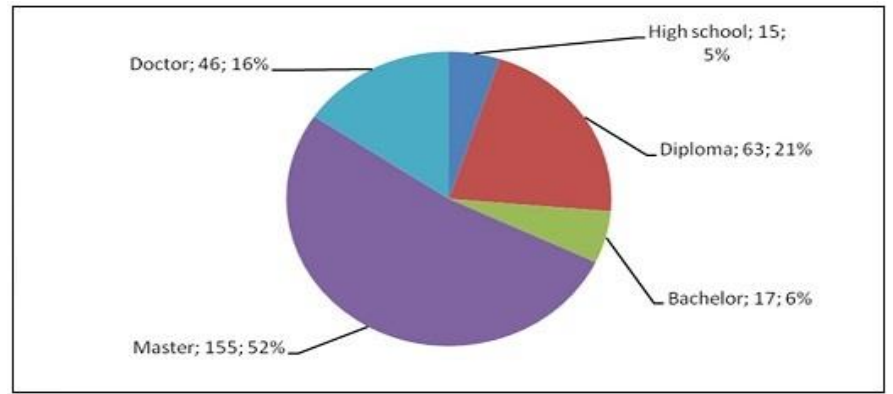

Figure 5. Education levels of the respondents

Fifth, project experience durations of the respondents. Majority respondents $(n=214 ; \pm 72 \%)$ experienced in the IS projects within more than two years Figure 6 . The highest rate $(n=85 ; \pm 28 \%)$ were the experienced actors within two to five years in the projects and the lowest rate $(n=51 ; \pm 17 \%)$ experienced within over 10 years.

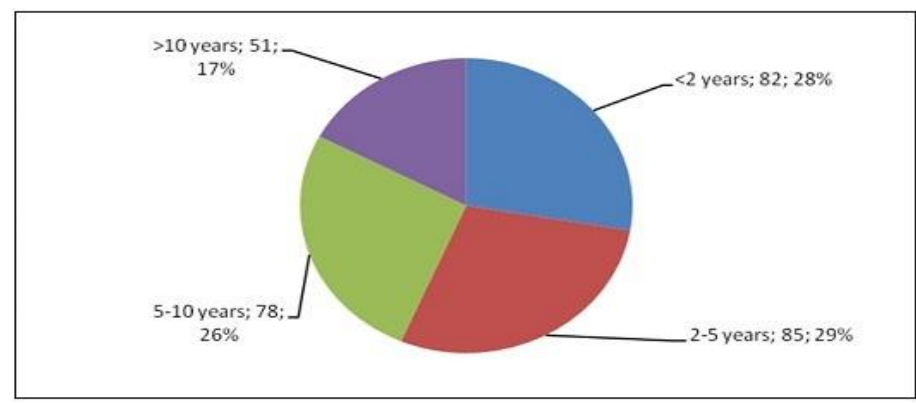

Figure 6. Project experience durations of the respondents

Sixth, job positions of the respondents. Figure 7 presents that the highest rate of the respondents $(\mathrm{n}=138 ; \pm 46.6 \%)$ was the project team members and the lowest one $(\mathrm{n}=11 ; 37 \%)$ was the project managers. The overall sampled people, who may have involved directly in the IS projects were around $68 \%(\mathrm{n}=202)$, including the team members $(n=138 ; \pm 46.6 \%)$, the project managers $(n=11 ; \pm 3.7 \%)$, and the IT unit managers $(n=53 ; \pm 17.9 \%)$. 


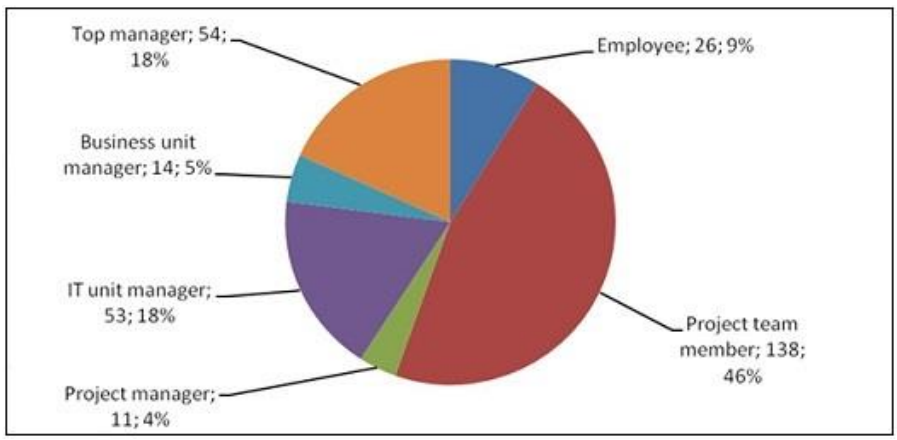

Figure 7. Job positions of the respondents

In short, despite the first information point (i.e., the respondent affiliation) may demonstrate the inconsistency indication with the contextual phenomenon of the study, but the five rest points (i.e., the institution accreditation, territory origin, education level, experience duration, and the job position) may present the consistency indications with the phenomenon. Therefore, the demographic information can be used relatively to justify the IS project profiles in the next sub-section.

\subsection{Profiles Of The Information System Projects}

There are the five profiles of the projects, including aims of the IS projects, availability of the IS strategic plan (ISSP), the involvement of the internal team, allocation of the internal budget, and level of the IS project success.

First, aims of the IS projects. Most of the sampled people $(n=201 ; 68 \%)$ revealed that the IS projects in their institutions aimed to support the operational business functions Figure 8. Meanwhile, the managerial and strategic aims were presented by the $49( \pm 17 \%)$ and $46( \pm 16 \%)$ people. This indication is consistent with findings of the previous studies $[4,5,18]$ that the project implementations are in regard to support the educational business and service operations of the institutions. It can also be seen, despite most of the HEIs may have focused on the operational functions; but the rest have been orienting to the managerial and strategic aims.

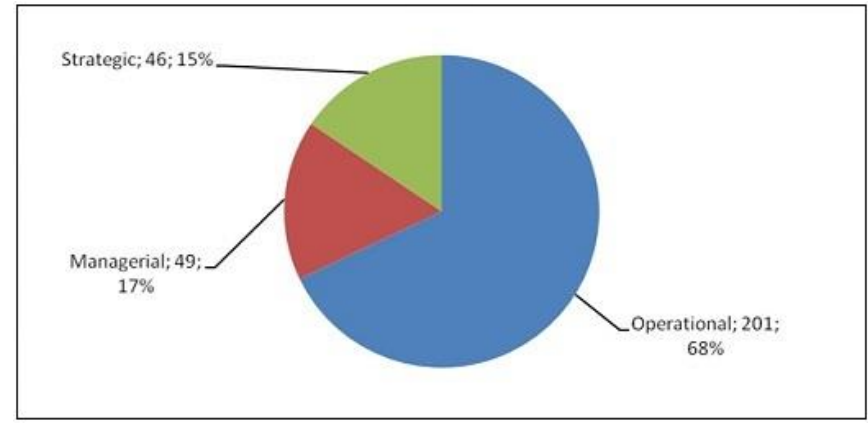

Figure 8. Aims of the IS projects

Second, availability of the ISSP. Majority respondents $(n=243 ; \pm 82 \%)$ indicated that their affiliations have ISSP, but the rest ones elucidated the contradiction indication Figure 9. In respect of the essential role of the planning towards the IS project performances [12-13, 30-31], the ISSP availability can be considered for estimating the project performances. As it is also indicated by the previous case studies [9, 14], the ISSP availability influences the project performances. Referring to the significance role, it can be predicted that most IS projects in the universities have been done following the developed ISSP.

Third, involvement of the internal team. The sampled respondents revealed relatively an average indication Figure 10. However, the highest number of the respondents $(n=96 ; \pm 32 \%)$ expressed that about $50 \%$ to $75 \%$ of the project team members are from the internal institutions and the lowest one $(n=39 ; \pm 13 \%)$ described that the number of the external people dominate $(>75 \%)$ the project team, but majority respondents $(\mathrm{n}=257, \pm 87 \%)$ expressed that more than two-third of the project team members are from the institutions themselves. It may indicate that the human resource availability of the IS projects among the sampled institutions is in the sufficient level. 


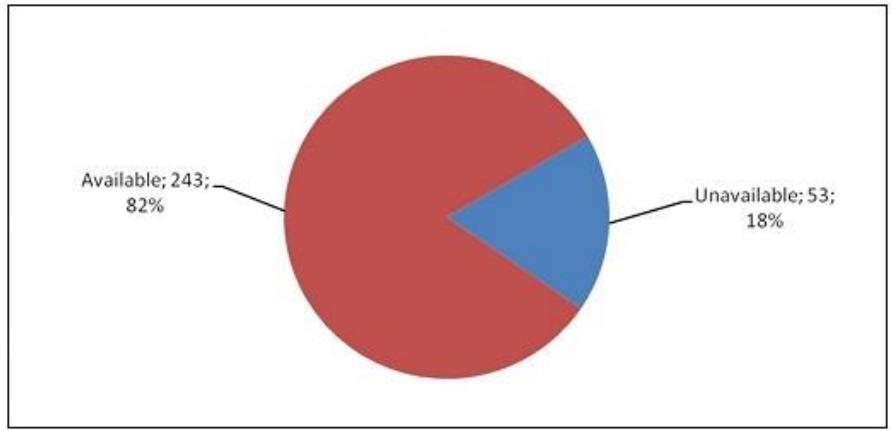

Figure 9. Availability of the ISSP

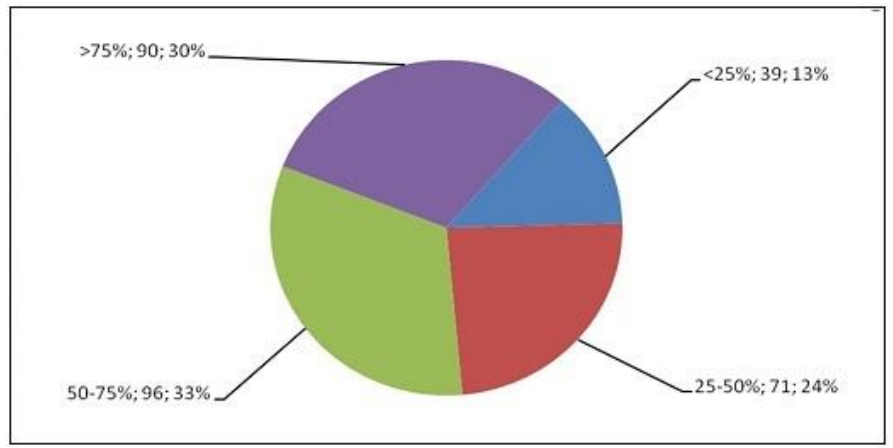

Figure 10. Involvements of the internal team

Fourth, allocations of the internal budget. As it is presented by Figure 11 below, the highest number $(n=142 ; \pm 48 \%)$ of the respondents expressed that more than $70 \%$ of the IS project budget in their HEIs were funded by the institutions. Whereas, the lowest number $(n=35 ; 11.8 \%)$ of these people expressed that the internal budget allocations were only under $25 \%$. It can also be seen that the more than half budget of the IS projects are also from the internal funding, as it was elucidated by almost $210( \pm 71 \%)$ sampled people. Retrospectively, this indication may be a proof of the Kunaefi's [32] descriptions that most projects have been initiated from the bottom-up initiative for more than three decades ago. He described that majority IS projects have done by the institutions themselves. Further, it may also a reasonable tendency referring to the accreditation rule of the sector in the country.

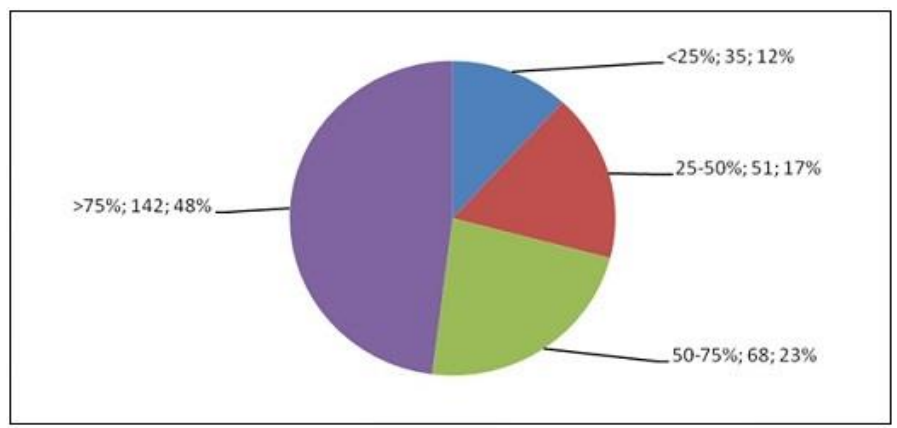

Figure 11. Allocations of the internal budget

Fifth, level of the IS project success. This study present that more than $50 \%$ of the IS project number among HEIs in Indonesia are categorized within the success level, as it was expressed by majority respondents $(n=243 ; \pm 82 \%)$ of the survey Figure 12 . Even approximately half of these sampled people 
$(\mathrm{n}=120 ; 40.5 \%)$ revealed that the number is more than $70 \%$. In contrast, it is only a few respondents $(n=6$, $\pm 2 \%$ ) who presented the success level is under $25 \%$. The above-mentioned indications may reasonable, in respect of the previous project profiles (see the ISSP availability point).

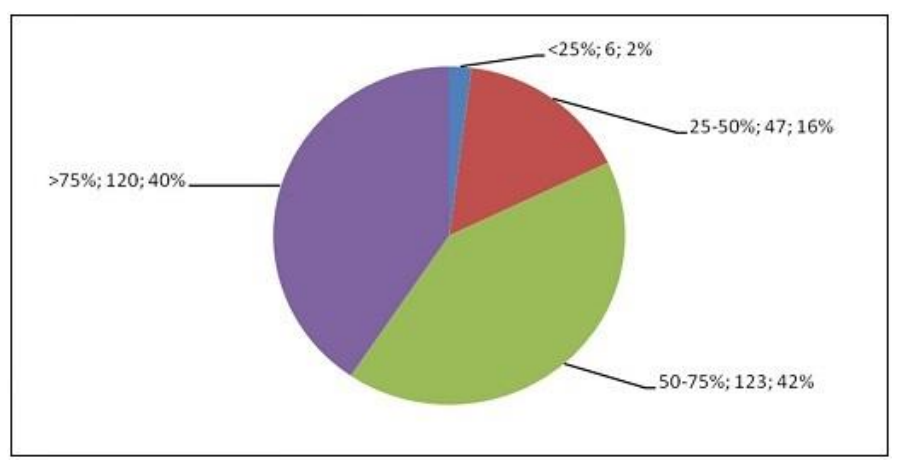

Figure 12. Degree of the IS project success

In brief, besides the IS project profiles can be confirmed by comparing with the respondent profiles, the findings presented here can also be justified with findings of the previous studies. For example, the interrelation between the ISSP availability and the project success level points. As it is revealed by prior studies $[10,14,30,31]$, it is clear that the ISSP availability of the institutions affect positively towards the IS project performances. In addition, referring to the research contribution studies [33], besides the findings may contribute how to know the status of the IS projects among HEIs based on perspectives of the internal project stakeholders; of course, the findings may also depend on several limitations of the study. The limitations may relate to the employment of the sampling technique, respondents, data collection technique, and the research instruments in this study. Therefore, the other studies may express the different findings following to the above-mentioned limitation points. Moreover, the further studies can be performed by considering the points, in order to produce the appropriate findings.

\section{CONCLUSION}

The IS utilizations may have been the determinant for the survival requirement of the HEIs in Indonesia. It may be one of the reasons why the IS implementations have been one of the main focuses of the institutions in the two last decades, in order to respond globalization and change in the higher education world. Despite the fact that, the IS development projects have been performed since more than three decades ago, but the performance of the projects seems like in the low level. Besides the contextual barriers of the higher education world in the nature and the theoretical and methodological gaps in the IS project success studies, the practical issues of the project implementations may also have been caused the low performances.

This study elucidated the status of the IS project success among the HEIs in the country referring to the internal stakeholder perspectives within four issues. That is the aim, ISSP availability, internal team involvement, internal budget allocation, and the success level of the IS projects. The findings may be part of the consideration points for the IS project stakeholders, in the context of the further performance studies. The further studies are recommended to consider several limitations of this study following the utilizations of the sampling technique, respondents, data collection technique, and the research instruments of the study.

\section{REFERENCES}

[1] McFarlan FW. "Information technology changes the way you compete: Harvard Business Review", Reprint Service; 1984.

[2] Kim LS. "Convergence of Information Technology and Corporate Strategy". Journal of the Korea Convergence Society. 2015;6(6):17-26.

[3] Wahyudin A, Hasibuan ZA, editors. "Research classification in strategic information system planning development: A critical review". 2015 International Conference on Science in Information Technology (ICSITech); 2015 27-28 Oct. 2015.

[4] Štefko R, Fedorko R, Bačík R. "The Role of E-marketing Tools in Constructing the Image of a Higher Education Institution". Procedia-Social and Behavioral Sciences. 2015;175:431-8. 
[5] Kamal B, Banu AT. "ICT in higher education-a study". Canadian Journal on Data, Information and Knowledge Engineering. 2010;1(1):1-12.

[6] Altbach P. "Globalization and forces for change in higher education". International Higher Education. 2015(50).

[7] Hughes DL, Dwivedi YK, Simintiras AC, Rana NP. "Project Failure and Its Contributing Factors". Success and Failure of IS/IT Projects: Springer; 2016. p. 3-25.

[8] Hughes LD, Rana NP, Simintiras AC. "The changing landscape of IS project failure: an examination of the key factors". Journal of Enterprise Information Management. 2017;30(1).

[9] Subiyakto A, Ahlan AR, Kartiwi M, Putra SJ, Durachman Y. "The User Satisfaction Perspectives of the Information System Projects". Indonesian Journal of Electrical Engineering and Computer Science (IJEECS). 2016;4(1).

[10] Subiyakto A, Ahlan AR, Kartiwi M, Sukmana HT. "Measurement of Information System Project Success Based on Perceptions of the Internal Stakeholders". International Journal of Electrical and Computer Engineering (IJECE). 2015;5(2):271-9.

[11] Subiyakto A, Septiandani D, Nurmiati E, Durachman Y, Kartiwi M, Ahlan AR. "Managers Perceptions towards the Success of E-Performance Reporting System". TELKOMNIKA (Telecommunication Computing Electronics and Control). 2017;15(3):1389-96.

[12] Subiyakto A, Ahlan AR, editors. "A coherent framework for understanding critical success factors of ICT project environment". 2013 International Conference on Research and Innovation in Information Systems (ICRIIS); 2013 27-28 Nov. 2013.

[13] Putra SJ, Subiyakto A, Ahlan AR, Kartiwi M. "A Coherent Framework for Understanding the Success of an Information System Project". TELKOMNIKA (Telecommunication, Computing, Electronics and Control). 2016;14(1):302-8.

[14] Subiyakto A, Ahlan AR, Kartiwi M, Putra SJ. "Measurement of the information system project success of the higher education institutions in Indonesia: a pilot study". International Journal of Business Information System. 2016;23(2):229-47.

[15] Hicks MJ. "Problem solving in business and management: hard, soft and creative approaches": Springer; 2013.

[16] Monsen JJ, Frederickson N. "The Monsen Problem-Solving Model". Frameworks for Practice in Educational Psychology: A Textbook for Trainees and Practitioners. 2016:95.

[17] Steffensen SV. "Human interactivity: problem-solving, solution-probing and verbal patterns in the wild". Cognition beyond the brain: Springer; 2013. p. 195-221.

[18] Xu X, Zhang W, Barkhi R. "IT infrastructure capabilities and IT project success: a development team perspective". Information Technology and Management. 2010;11(3):123-42.

[19] Ritchie B, Brindley C. "ICT adoption by SMEs: implications for relationships and management". New Technology, Work and Employment. 2005;20(3):205-17.

[20] Bouwman H, Van Den Hooff B, Van De Wijngaert L. "Information and communication technology in organizations: adoption, implementation, use and effects": Sage; 2005.

[21] Onwuegbuzie AJ, Collins KM. "A typology of mixed methods sampling designs in social science research". The qualitative report. 2007;12(2):281-316.

[22] Creswell JW. "Research design: Qualitative, quantitative, and mixed methods approaches": Sage publications; 2013.

[23] Blaxter L, Hughes C, Tight M. "How to research (ed.). Buckingham": Open University Press; 2001.

[24] Homburg C, Klarmann M, Reimann M, Schilke O. "What drives key informant accuracy?", Journal of Marketing Research. 2012;49(4):594-608.

[25] Demissie BS, Solomon AW. "Magnitude and causes of childhood blindness and severe visual impairment in Sekoru District, Southwest Ethiopia: a survey using the key informant method". Transactions of the Royal Society of Tropical Medicine and Hygiene. 2011;105(9):507-11.

[26] Teddlie C, Tashakkori A. "Foundations of mixed methods research: Integrating quantitative and qualitative approaches in the social and behavioral sciences": Sage Publications Inc; 2009.

[27] Heiervang E, Goodman R. "Advantages and limitations of web-based surveys: evidence from a child mental health survey". Social psychiatry and psychiatric epidemiology. 2011;46(1):69-76.

[28] LaGarce R, Washburn J. "An investigation into the effects of questionnaire format and color variations on mail survey response rates". Journal of technical writing and communication. 1995;25(1):57-70.

[29] Christopher J, Schertzer CB, Schertzer S. "Accounting Faculty Internships: A Descriptive Study". SAGE Open. 2013;3(3):1-18.

[30] Pearlson KE, Saunders CS, Galletta DF. "Managing and Using Information Systems, Binder Ready Version: A Strategic Approach": John Wiley \& Sons; 2016.

[31] Besson P, Rowe F. "Strategizing information systems-enabled organizational transformation: A transdisciplinary review and new directions". The Journal of Strategic Information Systems. 2012;21(2):103-24.

[32] Kunaefi TD, editor. "ICT in University Teaching/Learning and Research in Southeast Asian Countries: A Case of Indonesia". Regional Seminar on Making a Difference: ICT in University Teaching/Learning and Research in Southeast Asian Countries Indonesia; 2007; Jakarta.

[33] Whetten DA. "What constitutes a theoretical contribution?". Academy of management review. 1989;14(4):490-5 